Soviet universities

\section{The largest system anywhere}

By any yardstick, Soviet higher education is gargantuan. The student population is roughly 5 million, with more than a million students recruited every year. These people are educated in a total of nearly 1,000 institutions of various kinds ( 896 to be precise), most of them with a vocational bent (towards medicine, management or foreign languages, for example). There are 69 institutions known as universities on account of the catholic range of courses on offer.

The standard curriculum requires that a student should take five years over a first degree (but institutions such as the Moscow Physical-Technical Institute allow their undergraduates six years). The first three years of the first-degree course are spent within the walls of the institution concerned, but afterwards a student will be transferred physically to an establishment of a different kind (from a university science department to a research institute, for example, or from a pedagogical institute to a school).

Entry to higher education is competitive, and based on performance in a national school-leaving examination, but some universities run their own competitive examinations to select from among otherwise qualified applicants. For the Soviet Union as a whole, and for institutions of all kinds, the proportion of highschool leavers going on to higher education is just under 20 per cent.

It is a sign of the times in the Soviet Union that the University of Leningrad is planning to advance the date of its own examination from August to July each year so as to be able to compete more effectively for the able students at present creamed off by the State University of Moscow, whose examination has traditionally been in July.

The competition for able students, especially among the universities, appears to have intensified in recent years, partly as institutions have come to recognize that their long-term future will be largely determined by the eagerness with which their graduates are welcomed into the labour-force. The result is that, as in the beleagured British university system, universities have taken to persuading their teachers to excite the interest of potential applicants by delivering popular lectures on some aspect of their science.

Universities and polytechnics (as distinct from monotechnics), being the chief source of recruits for the research institutes, necessarily have close ties with members of institute staffs, many of whom will be nominated as professors and who may, in that role, be responsible both for organizing the whole of the teaching in their special fields and for providing the teachers, usually from among immediate subordinates at their institutes.

The practice seems to vary from place to place, but there are at least some places (the University of Novosibirsk, for example, see page 795 where particular institutes are responsible not merely for education during the closing phase of a first degree but for the first three years as well. First degrees are awarded by universities themselves, but most research degrees are the responsibility of scientific councils of research institutes subject to the approval of national accreditation commissions.

The exceptions are the research degrees awarded directly by those universities that have been able to retain their own research institutes in particular fields. The Moscow State University, even by the consent of its rivals, is the outstanding multivalent university of this kind, but Leningrad (page 796) is also proud of having kept some research capacity within its walls.

Either way, the award of a research degree is a fearsome business. Both Candidates' (PhD) degrees and DScs are awarded on the basis of a thesis (usually a published monograph in the second case). The awarding authority is obliged to circulate copies of the thesis to people knowledgeable in the field, each of whom is entitled to submit critical comments for consideration by the examining board.
(Many do, by all accounts.) Finally, the thesis must be defended in public by the applicant, with or without assistance from members of the audience, any of whom is entitled to intervene.

Soviet universities appear to be more like educational mills, if also less confusing, than their counterparts in the West. Part of the explanation is that departments deeply penetrated by the external research institutes with which they are associated are necessarily somewhat isolated from others. Where the curriculum is dominated by a specialized institute, the pattern of teaching also appears inflexible. Why should a bunch of plasma physicists be sensitive to the needs of biologists, for example?

The isolation of vocational education, for example medicine, in separate institutions also deprives Soviet universities of the multi-faceted character called richness in the West. If universities (other than Moscow and Leningrad) were more directly engaged in research, there would be serious difficulties about interdisciplinary coordination; as things are, coordination must be sought through the cumbersome high-level committees involving academies or even ministries.

The Minister of Higher Education, who has contentious problems on his immediate agenda, seems content with the present structural arrangements; in due course, he may find it worth while to seek a merger of vocational schools with existing universities so as to create more interesting institutions (whose administration might be simpler).

\section{Rationalization \\ Hunt for quality amid quantity}

Minister of Higher Education Dr G.A. and demand for specialized labour, which Yagodin, appointed by Mr Gorbachev is understandable in one who was earlier this year to a crucial and previously neglected post, has saddled himself with an invidious task: he is committed to carrying out an evaluation of the quality of the institutions of higher education throughout the Soviet Union so as to tell which should be encouraged to grow and which to shrink.

Only recently, he says with some pride, his ministry has actually closed an institution - the economics institute (essentially a management school) at Baku in Azerbaijan (see p. 783), opening a branch of the Leningrad Institute of Economics there instead. But he has not yet experienced the full fury of important academic institutions scorned.

Yagodin, a vigorous man in his midfifties, speaks English excellently, on the strength of a two-year spell studying chemical engineering at Imperial College, London. He talks of the function of higher education in rounded social terms, not merely those appropriate to the supply snatched away from the rectorship of a university to his present post.

Yagodin does not regard the prospect of evaluating university quality and performance with quite the trepidation that the recent experience of the University Grants Committee in Britain might suggest. "We have no difficulty about Moscow, Leningrad or Tomsk", he says. Most of his difficulties will arise from dealings with the small vocational schools scattered about the country, but the evaluation could also raise national hackles in various of the republics.

For the rest, the process of evaluation will have to be continuous. He plans to set up a system in which outside inspectors will visit universities observing how undergraduates spend their time, on what, and often exercising their right to examine the students to form an objective estimate of what they have learned.

Yagodin goes out of his way to deny the outsider's impression that the quality of 